\title{
A New Record of Ratan Goby - Ponticola Ratan (Nordmann, 1840)(Pisces: Gobiidae) in the Black Sea, Romanian Coastal Waters
}

\author{
Daniel Ioan COCAN ${ }^{1}$, Vasile OȚEL ${ }^{2}$, Călin LAȚIU ${ }^{1}$, Vioara MIREŞAN ${ }^{1 *}$ \\ ${ }^{1}$ Faculty of Animal Science and Biotechnologies, University of Agricultural Sciences and Veterinary \\ Medicine Cluj-Napoca, 3-5 Mănăştur Street, 400372, Cluj-Napoca, Romania \\ ${ }^{2}$ Danube Delta National Institute for Research and Development - Tulcea. 165 Babadag St., Tulcea, \\ 820112, Romania \\ * corresponding author: vmiresan@yahoo.com
}

Bulletin UASVM Animal Science and Biotechnologies 73(2)/ 2016

Print ISSN 1843-5262; Electronic ISSN 1843-536X

DOI:10.15835/buasvmcn-asb: 12220

\begin{abstract}
In August 2015 we managed to capture a specimen of ratan goby (Ponticola ratan) in the Romanian coastal waters of the Black Sea, near the locality of Sf. Gheorghe (Tulcea County).This is the $7^{\text {th }}$ signaling for this species in Romanian coastal waters. The previous 6 specimens were recorded in the period 1960-1993, between Mangalia (Constanța County) and Sulina (Tulcea County). The species was identified by means of meristic characters (number of scales on medial line, number of spiny and soft rays), and morphological particularities (cycloid scales on the nape area and pectoral fin joint). Also, the measurements made, confirmed that the ratio between the head length and total length, which was $33 \%$ (TL=8.70 $\mathrm{cm}$ vs. Head Length $=2.61 \mathrm{~cm}$ ). Another morphological character, specific to this species, is the lower jaw, which exceeds in length the upper jaw. Being a Ponto-Caspianendemite, with low population along the Bulgarian and Romanian coastline, we considered it important to point out this new record. Noting that, being known the trend of sporadic migration of this species, would not be excluded that global warming causes a shift from its normal distribution area, from northern and northeastern (Black Sea) to south-west.Therefore, future research may bring more notifications regarding this species in south-western area of the Black Sea.
\end{abstract}

Keywords: Ponticola ratan, Black Sea, new signaling, migration

\section{INTRODUCTION}

The ratan goby (Ponticola ratan) is a PontoCaspianendemite. The distribution area of this species covers the northern and northeastern coastal waters of the Black Sea and the southern limit is represented by the Bulgarian coastal waters. The ratan goby is also found in the Azov Sea. In the Caspian Sea it is found in the central part of the west coast and the southeastern coast (Bănărescu, 1964; Miller, 2003; Neilson and Stepien, 2009; Oțel, 2007; Vasilieva, 2007). It is more widespread in northern, north-eastern Black Sea coast and rarely in the coastal waters of Bulgaria and Romania.
It is aneuryhalin species and prefers sea areas with sandy or rocky substrate (Miller, 2003; Oțel, 2007; Vasilieva, 2007), but can also be seen on the muddy bottom substrate (Miller, 2003). Comfort limits for salinity are mentioned: 6-16\%o (Vasilieva, 2007), but there were cases when this species was found in freshwaters such as the Dnieper, Dnieper-Donbass canal (Manilo and Didenko, 2013). It is also mentioned that sometimes tends migration (Miller, 2003).

During the period $1960-1964$ in the Romanian Black Sea coastline were captured a total of 5 specimens (Bănărescu, 1964): one near Mangalia (Constanța County) and 4 near Sulina 
Tab. 1.Meristic counts for Ponticola ratan

\begin{tabular}{cccccc}
\hline Authors & D1 & D2 & A & P & SqL \\
\hline Georghiev, 1966 & (V)VI(VII) & $\mathrm{I}(15) 16-18(19)$ & $\mathrm{I}(12) 13-14(15)$ & $(18) 19-20(21)$ & $(52,53) 54-59(60-61)$ \\
\hline Manilo and Didenko, 2013 & VI & $\mathrm{I}(15) 16-17$ & $\mathrm{I} 13-14$ & $18-19$ & $50-54$ \\
\hline Bănărescu, 1964 & VI & $\mathrm{I} 15-18$ & $\mathrm{I}(11) 12-14$ & - & $(45) 47-55(58)$ \\
\hline MSIP & VI(V-VII) & $\mathrm{I} 16-18(15-19)$ & $\mathrm{I} 13-14(12-15)$ & $19-20(18-21)$ & $54-59(52-61)$ \\
\hline Our research, 2016 & VI & $\mathrm{I} 16$ & $\mathrm{I} 12$ & 19 & 53 \\
\hline
\end{tabular}

Note: D1-dorsal fin 1; D2-dorsal fin 2; A-anal fin; P-pectoral fin; SLL-scales on median line; MSIP-marine species identification portal (www. species-identification.org)

(Tulcea county), and in 1993 the $6^{\text {-th }}$ specimen was captured near Gura Portiței (Oțel, 2007). Meristic counts and somatic data are published only for the specimen collected from Mangalia (Bănărescu, 1964).

\section{AIMS AND OBJECTIVES}

In the context of climate change and human impact on the natural environment, we intend to establish the causes of the migration routes changes and the migration seasons of fish, in this case the ratan goby, in the Black Sea romanian coastal waters.

\section{MATERIALS AND METHODS}

Our ratan goby specimen was captured in the Black Sea, near the locality of Sf. Gheorghe (N 44.882724 - 29.631970 E), Tulcea County, by angling. Water depth was about $6 \mathrm{~m}$ on a sandy substrate and at a distance of $800 \mathrm{~m}$ from the shore. Our measurements were made after preservation of the specimen in alcohol. The identification of species was made on the basis of specific morphological characters and features of the scales.

\section{RESULTS AND DISCUSSION}

Meristic counts and somatic data performed, were compared to other authors data, and demonstrates the identity of the species (Table 1).

Also, the variables taken out, correspond for this species: cycloid scales on the nape and ctenoid scales on the rest of the body. The ratio of the head length is $33 \%$ from the total length. The lower jaw is slightly above the upper jaw and the upper lip is narrower compared to other species of gobies, keeping the same width in the oral region and up to the corners.The pelvic sucker is slightly lobed reaching up to the anus, the caudal peduncle is short and slightly laterally compressed.Therefore, our catchfrom August 2015 in the Black Sea, near the locality Sf. Gheorghe (Tulcea County) is the $7^{\text {th }}$ specimen of Ponticola ratan within the last 55 years for Romania.The rarity of this species in the west / south-west area of the Black Sea is probably due to its distribution limit in this geographical area. Being known the migratory trends of this species, it is possible that global warming can cause the migration from northeast to the southeast. Such migrations are already known (from Asia to Europe) in some species of birds (Kiss and Szabo, 2000). We find a surprising migration of the Percarina demidoffii, which in 1984 was recorded for the first time in large numbers in the lagoon complex of Razim-Sinoe (Oțel and Bănărescu, 1986; Oțel, 2006), where currently there is a stable population, coming from rivers firths flowing into the northern Black Sea (Ukraine).

\section{CONCLUSION}

The climate change, the human impact on the natural environment and the loss of Romanian fishing ships made an important change in fish population. Because of this, a lot of species from the Black Sea, which were consider disappeared or rare, are now found in Romanian coastal waters.

\section{REFERENCES}

1. Bănărescu P (1964). Fauna Republicii Populare Române, Pisces-Osteichthyes, Vol. XIII, Ed. Acad. R.P.R., Bucureşti: 845-846.

2. Georghiev JM (1966). Some new and little known gobies (Gobiidae, Pisces) in Bulgarian ichthyofauna. Bull. Res. Inst. Fish. Oceanogr., 7: 159-228.

3. Manilo LG, Didenko AV (2013). A record of the ratan goby, Ponticola ratan (Gobiidae, Perciformes), in the Dneprodzerzhinsk reservoir (Dnieper river). Vestnik zoologii, 47(4): 335-341.

4. Miller JP (2003). The Freshwater Fishes of Europe, Vol.8/I, Mugilidae, Atherinidae, Atherinopsidae, Blenniidae, Odontobutidae, Gobiidae 1. Aula-Verlag: 356 - 369.

5. Neilson ME, Stepien CA (2009). Escape from the PontoCaspian: Evolution and biogeography of an endemic goby species flock (Benthophilinae: Gobiidae: teleostei). Molecular Phylogenetics and Evolution, 52(1): 84-102. 
6. Oțel V, Bănărescu P (1986). First record of Percarina demidofii Nornmann, 1840 from Romania and from the Danube river basin (Pisces, Percidae). Rev. Roum. Biol. 31(1):11-13.

7. Oțel V (2006). Status of Percarina demidoffii Nordmann, 1840 (Pisces, Percidae) after two decades of its recording in Romania. Acta Ichtiologica Romanica, Sibiu, I: 215-220.

8. Oțel V (2007). Atlasul peștilor din Rezervația Biosferei Delta Dunării. Ed. Centrul de Informare Tehnologică Delta Dunării: 353-355.
9. Vasilieva DE (2007). Fishes of the Black Sea. VNIRO, Moscow: 167-168.

10. Kiss JB, Szabo L (2000). Der Weissschwanzkiebitz Vanellus leucurus als europäischer Brutvogel im Donaudelta. Limnicola, 14(3): 113-123.

11. www.species-identification.org 